Mr Aleksandar Kari, kapetan I klase, dipl. inž.

Vojna akademija,

dr Momčilo Milinović,

dipl. inž.

Mašinski fakultet,

Beogra
BORBENO OPTEREĆENJE VIŠECEVNOG LANSERA USLED DEJSTVA UDARNOG TALASA

UDC: 623.428 .84

Rezime:

U radu su obrađene osnovne karakteristike borbenog opterećenja samohodnog višecevnog lansera raketa sa aspekta mehanike borbene žilavosti. Različite amplitude udarnih talasa iniciraju granične sile $i$ momente koji deluju na bočnu stranu lansera $i$ narušavaju stabilnost lansera $i$ bezbednost raketne municije. Utvrđen je profil impulsnog opterećenja višecevnog lansera raketa pod dejstvom udarnog talasa nastalog hipotetičkim pogotkom u njegovoj neposrednoj blizini i postavljeni su uslovi stabilnosti tako pogođenog lansera.

Ključne reči: višecevni lanser, borbeno opterećenje, udarni talas, stabilnost.

\title{
COMBAT LOADING OF MLRS UNDER SHOCK WAVE IMPULSE
}

Summary:

This paper considers behavior of basic performances of combat survivability for MLRS of short tactical ranges. Different shock wave amplitudes initiate threshold forces and moments acting on MLRS lateral sides and disturbing launcher stability and rocket ammunition safety. A mathematical model takes into account impulse shock wave loading caused by $H E$ projectiles and gives stability conditions of MLRS.

Key words: MLRS, combat loading, shock wave, stability.

\section{Uvod}

Pri gađanju višecevnim lanserima raketa koji koriste fiksne cevi integrisane na lansirnu kutiju, namenjene za višekratnu upotrebu, najčešće se prelazak sa jednog vatrenog položaja na drugi, kao i prelazak sa rezervnog na vatreni položaj vrši u uslovima intenzivnog kontrabatiranja ili neispaljenog rafala napunjenog lansera. Tada raketa trpi posebna opterećenja gasodinamičkih impulsnih udara na koja obično nije proverena važećim standardima za kontrolno-tehnička gađanja. Ova opterećenja i amplitudno i frekventno predstavljaju karakteristične slučajeve koji nisu propisani važećim vojnim standar- dima već se tretiraju kao koncept ispitivanja borbene žilavosti oruđa i municije.

Udarni talas koji nastaje usled eksplozije u neposrednoj blizini samohodnog višecevnog lansera raketa može izazvati različite efekte na sam lanser. Ti efekti najčešće se javljaju kao impulsne sile natpritiska udarnog talasa koji menja svoj oblik i intenzitet, prelazeći preko profila samohodnog sistema zavisno od pravca iz kojeg dolazi (slika 1). Posledice takvih promena formiraju rezultujuću dinamičku silu koja izaziva:

- oscilacije samog lansera,

- eventualno prevrtanje ili destabilizaciju,

- potpuno ili delimično uništavanje, $\mathrm{i}$ 
- aktiviranje raketa na platformi za punjenje lansera ili u cevima.

Svaki od navedenih efekata zavisi od niza faktora od kojih su najvažniji:

- rastojanje i intenzitet primarnog izvora eksplozije (dakle, položaj pogotka po koordinatnom zakonu uništenja),

- sama čvrstoća i oblik samohodnog lansera i pouzdanost mehanizama napunjene municije,

- osetljivost funkcije lansirnog oruđa na promene koje mogu da izazovu kratkovremene dinamičke sile.

\section{Formiranje opterećenja usled udarnog talasa}

Za formiranje opterećenja usled udarnog talasa nastalog zbog eksplozije projektila u neposrednoj blizini samohodnog lansera formiran je fizički model koji je uprošćeno prikazan na slikama 1 i 2.

$\mathrm{Na}$ sistem deluje poremećajna sila $\mathrm{P}$ talasa, nastalog usled eksplozije projektila na udaljenosti r od samohodnog lansera [1].
Glavne karakteristike udarnog talasa su natpritisak na frontu udarnog talasa i trajanje impulsa, čije vrednosti zavise od vrste eksploziva, mase eksploziva i udaljenosti od mesta eksplozije. Na osnovu eksperimentalnih rezultata, za sferične udarne talase koji nastaju detonacijom određene mase TNT, Sadovski [2] je predložio empirijsku formulu za proračun natpritiska na frontu udarnog talasa $u$ obliku:

$\Delta p=k_{1} \frac{m_{e}^{\frac{1}{3}}}{r}+k_{2} \frac{m_{e}^{\frac{2}{3}}}{r^{2}}+k_{3} \frac{m_{e}}{r^{3}}[\mathrm{bar}]$

gde su:

$\mathrm{m}_{\mathrm{e}}-$ masa eksplozivnog punjenja $\mathrm{u} \mathrm{kg}$, $r$ - udaljenost od centra eksplozije u m, $\mathrm{k}_{1}, \mathrm{k}_{2}, \mathrm{k}_{3}$ - empirijski koeficijenti koji zavise od vrste eksplozivnog punjenja, a profil zadat $\mathrm{u}$ vremenu prikazan je na slici 2 .

Za eksploziv tipa TNT, kao i za ostale eksplozive srednje snage, u slučaju

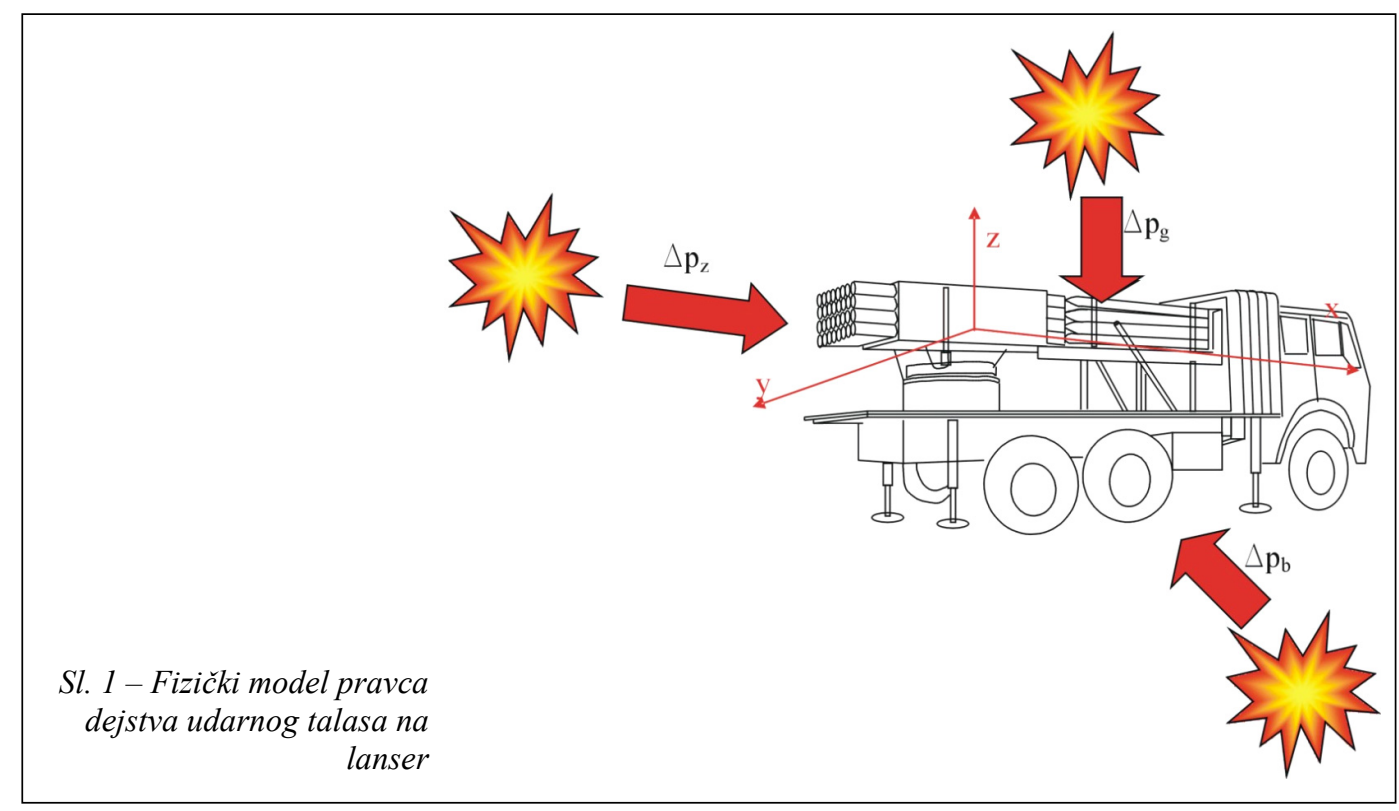


nadzemne eksplozije usvajaju se vrednosti empirijskih koeficijenata $\mathrm{k}_{1}=0,85 ; \mathrm{k}_{2}$ $=3 ; \mathrm{k}_{3}=8$. U slučaju površinske eksplozije, udarni talas u vazduhu se širi u obli$\mathrm{ku}$ polusfere (duplo manja zapremina), pa je natpritisak u tom slučaju veći. Tada se najčešće $u$ izrazu (1) za masu punjenja uzima dvostruka masa [2]. Kako pri površinskoj eksploziji dolazi i do deformacije tla potrebno je uvesti i koeficijent $\eta$ koji zavisi od vrste tla (tabela), pa je proračunska masa eksploziva u izrazu (1): $\mathrm{m}_{\mathrm{p}}=2 \eta \mathrm{m}_{\mathrm{e}}$.

\begin{tabular}{|c|c|c|c|c|c|c|}
\hline $\begin{array}{c}\text { Tip } \\
\text { prepreke }\end{array}$ & $\begin{array}{l}\text { Čelična } \\
\text { ploča }\end{array}$ & $\begin{array}{l}\text { Armirana } \\
\text { betonska } \\
\text { ploča }\end{array}$ & $\begin{array}{l}\text { Beton, } \\
\text { stena }\end{array}$ & $\begin{array}{c}\text { Tvrdo } \\
\text { zemljište }\end{array}$ & $\begin{array}{c}\text { Srednje- } \\
\text { tvrdo } \\
\text { zemljište }\end{array}$ & Voda \\
\hline$\eta$ & 1 & $0,95-1$ & $0,85-0,9$ & $0,7-0,8$ & $0,6-0,65 \mid 0$ & $0,55-0,6$ \\
\hline
\end{tabular}

Uz usvajanje da je do eksplozije došlo na tvrdom zemljištu $(\eta \approx 0,75)$, koeficijenti u izrazu (1) dobijaju sledeće vrednosti:

$k_{1}=0,97 ; k_{2}=3,93 ; k_{3}=12$

Dejstvo eksplozije na većim rastojanjima od mesta eksplozije $r$ ostvaruje se zahvaljujući kretanju talasa sabijanja i talasa razređenja vazduha. Zavisnost pritiska od udaljenosti od centra eksplozije i vremena prikazana je na slici 2 [3].

Vreme dejstva pozitivne faze natpritiska predstavlja važnu praktičnu karakteristiku udarnog talasa, jer bitno utiče na efekat rušećeg dejstva.

$\mathrm{Na}$ osnovu eksperimentalnih rezultata i numeričkog modeliranja utvrđen je sledeći izraz za izračunavanje vremena dejstva udarnog talasa [3]

$$
\tau=0,0015 \sqrt[6]{m_{e}} \sqrt{r}
$$

gde su:

$\mathrm{m}_{\mathrm{e}}-$ masa eksplozivnog punjenja u kilogramima,

$r$ - udaljenost od centra eksplozije u metrima, a $\tau$ se računa u sekundama.

Sa određenim približenjem [3] može se uzeti da je:

$\tau=\frac{r}{2 c} \sqrt[6]{\frac{m_{e}}{r^{3}}}$

gde je c - brzina zvuka.

Zavisno od vremena trajanja pozitivne faze natpritiska dominantno dejstvo nastaje usled intenziteta natpritiska ili usled veličine impulsa natpritiska $[4,5]$ :

$I=\int_{0}^{\tau} p(t) d t$

gde je $\mathrm{p}(\mathrm{t})$ - natpritisak $\mathrm{u}$ nekom trenutku t nakon prolaska čela udarnog talasa.

Vrednost impulsa udarnog talasa može se proceniti na osnovu eksperimentalne matematičke aproksimacije natpritiska u zavisnosti od vremena [4]:

$$
p(t)=\Delta p\left(1-\frac{t}{\tau}\right) \cdot e^{-\frac{t}{\tau}}
$$

Raspodela opterećenja natpritiska na lanser u toku dejstva eksplozije prikazana je po fazama kretanja preko širine vozila pri bočnom dejstvu eksplozije i raspoređena kao aproksimacija za prostiranje talasa preko zatvorenog kvadra u tri karakteristične ravni po širini vozila (slike 3 i 4) $[4,5]$. 


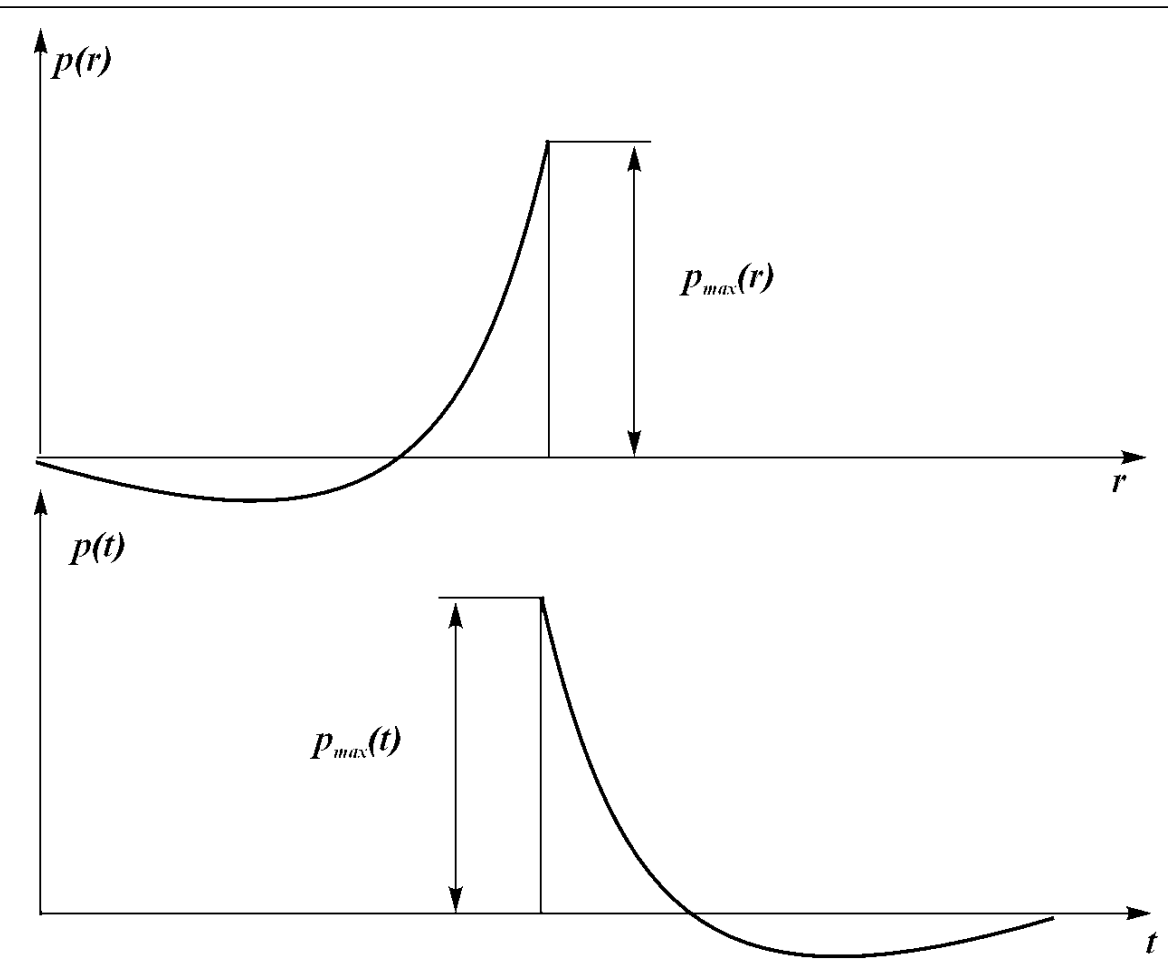

Sl. 2 - Promena pritiska udarnog talasa

Nakon takvog bočnog opstrujavanja širine vozila pokretnim udarnim talasom dolazi do deformacije profila natpritiska po širini vozila tokom vremena od momenta nailaska pa do izlaska udarnog talasa sa naspramne bočne strane duž y ose. Navedene deformacije poslužiće za približnu procenu intenziteta natpritiska i pozitivne faze impulsa pritiska sa aspekta ocene opterećenja raketa u lanseru i na borbenoj platformi.

Ukupna aproksimacija bočnog natpritiska, kao impulsna pobuda, predstavlja razliku natpritiska svedenu na bočnu površinu siluete vozila u početnom trenutku. To je osnova za proračun merodavne impulsne sile koja može da izazove pomenute efekte ugrožavanja borbene žilavosti lansera napunjenog raketnom municijom. Ta vrednost može se proceniti [6] prema izrazu:

$$
\Delta p_{s k}=\frac{2,5 \cdot \Delta p_{b}{ }^{2}}{\Delta p_{b}+709205}
$$

Pošto udarni talas menja profil natpritiska sa gornje strane i pri bočnom opstrujavanju, usvojen je približni model rešenja rezultujućeg efekta dobijen superpozicijom profila natpritisaka, datog na slici 3, pri dejstvu sa boka i opstrujavanju odozgo prostornog paralelograma približnih dimenzija samohodnog lansera (slika 4).

Važno je naglasiti da precizno utvrđivanje prostiranja udarnog talasa preko karakterističnih površina samohodnog 

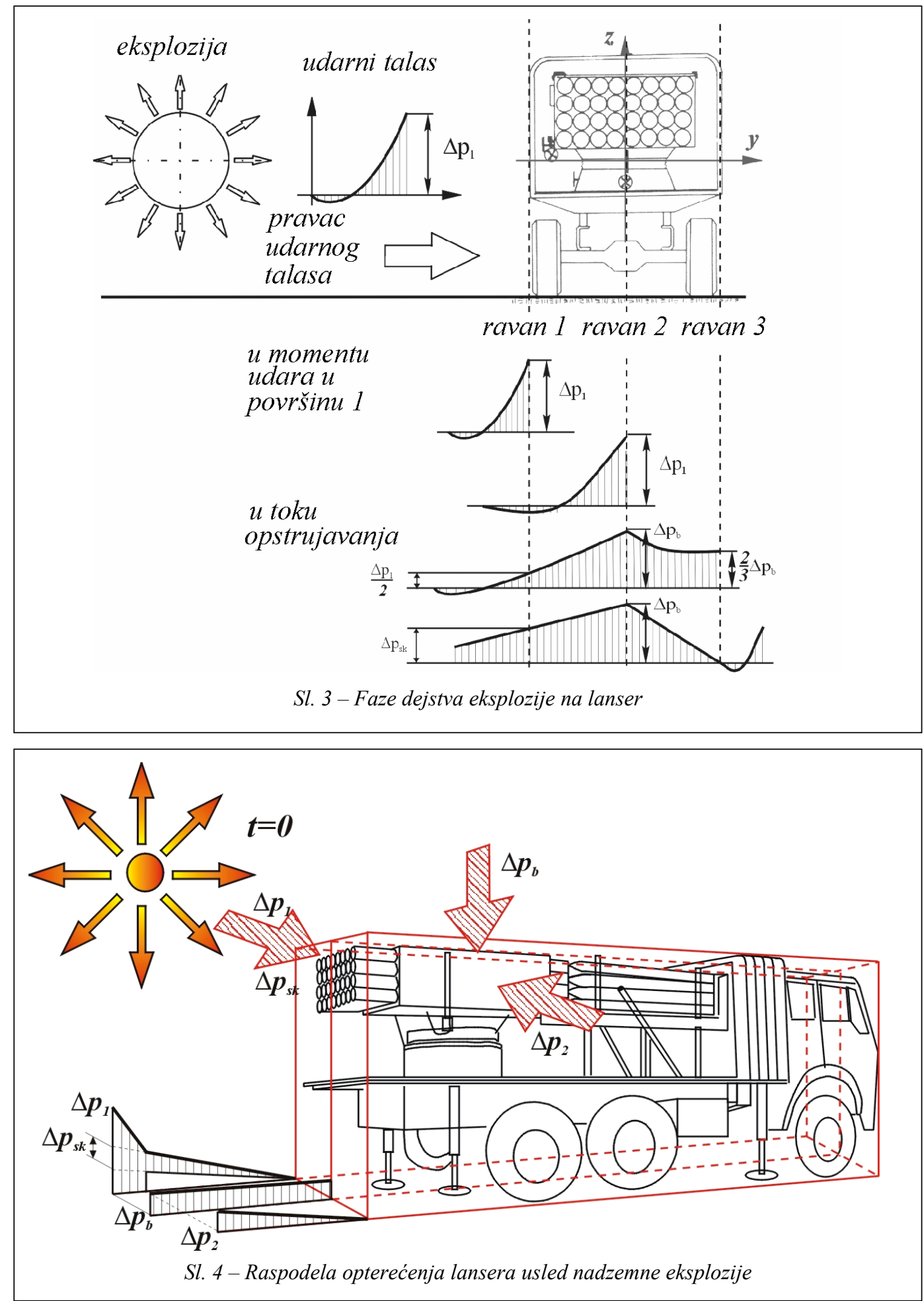
lansera po širini ili po dužini predstavlja vrlo složen matematički model, koji se čak i sa najboljim softverskim paketima ne može pouzdano oceniti. Ovakve sile se najčešće utvrđuju na poligonu eksperimentalnim merenjima, tako da ovaj pokušaj predstavlja samo idejnu aproksimaciju pitanja fizičkih procesa koji još nisu standardizovani i uobličeni u matematički aparat konstruktorskih i prototipskih simulacionih ispitivanja.

Opterećenje koje deluje na ukupnu površinu siluete samohodnog lansera ima distribuciju natpritiska u toku vremena $\mathrm{u}$ formi modifikovanog oblika impulsnog udarnog talasa.

Maksimalni natpritisak, koji deluje na bočnu stranu lansera, dakle, iznosi:

$$
p_{\max }=c_{y} \cdot p_{s k}
$$

gde je:

$\mathrm{p}_{\mathrm{sk}}$ - rezultujući efektivni pritisak bočnog opstrujavanja lansera čiji je koeficijent otpora proporcionalan opstrujavanju $\mathrm{c}_{\mathrm{y}}$.

Ovakav natpritisak izaziva različite efekte dejstva rezultujućih sila, kao što su translatorna pomeranja i rotaciona ljuljanja u momentu udara, izazvana momentima oko tačaka oslanjanja podsklopova i celog samohodnog lansera.

\section{Dejstvo sila i momenata i uslovi stabilnosti samohodnog lansera usled impulsnog natpritiska}

Stabilnost lansera na navedene efekte pomeranja pri dejstvu sile natpritiska $\mathrm{P}$, bočno na lanser, može se izraziti izrazima kojima se definiše ravnoteža sila u dva ortogonalna pravca (slika 5) i obezbeđuje proračun sigurnosti od prevrtanja, ali ne i sigurnosti od aktiviranja raketne municije. Ti izrazi glase $[4,6]$ :

$$
\begin{aligned}
& P-\left(T_{1}+T_{2}\right)=0 \\
& T_{1}+T_{2}=f(Q+G)
\end{aligned}
$$

gde su:

$\mathrm{Q}=\Delta \mathrm{p}_{\mathrm{b}} \cdot \mathrm{A}_{\mathrm{G}}-$ rezultujuća sila natpritiska udarnog talasa sa gornje strane vozila na gornju površinu lansera $A_{G}$,

$\mathrm{G}$ - sila težine punog lansera, P - bočna rezultujuća sila izazvana eksplozijom čija je vrednost

$P=c_{y} \cdot \frac{2,5 \Delta p_{b}^{2}}{\Delta p_{b}+709205} \cdot A_{b},[\mathrm{~Pa}]$

f - koeficijent trenja oslanjanja samohodnog lansera pri mirovanju ili kotrljanja pri kretanju.

Rešenjem jednačina (8), (9) i (10) dobija se izraz:

$$
c_{y} \cdot \frac{2,5 \Delta p_{b}^{2}}{\Delta p_{b}+709205} \cdot A_{b}=f \cdot\left(\Delta p_{b} \cdot A_{G}+G\right)
$$

koji predstavlja silu koja izaziva bočno translatorno kretanje (proklizavanje), iz koje se može odrediti granični intenzitet udarnog talasa $\Delta \mathrm{p}_{\mathrm{b}}$, koji bi doveo do bočnog pomeranja ili prevrtanja lansera $u$ toku dejstva eksplozije.

Da bi se utvrdilo pitanje proklizavanja ili prevrtanja bilo bi potrebno poznavati centar dejstva natpritiska u odnosu na horizontalnu ravan oslanjanja. Pošto to nije predmet ovog rada, stabilnost od prevrtanja neće biti tretirana, već se samo pominje kao fenomen za dalju analizu borbene žilavosti. 


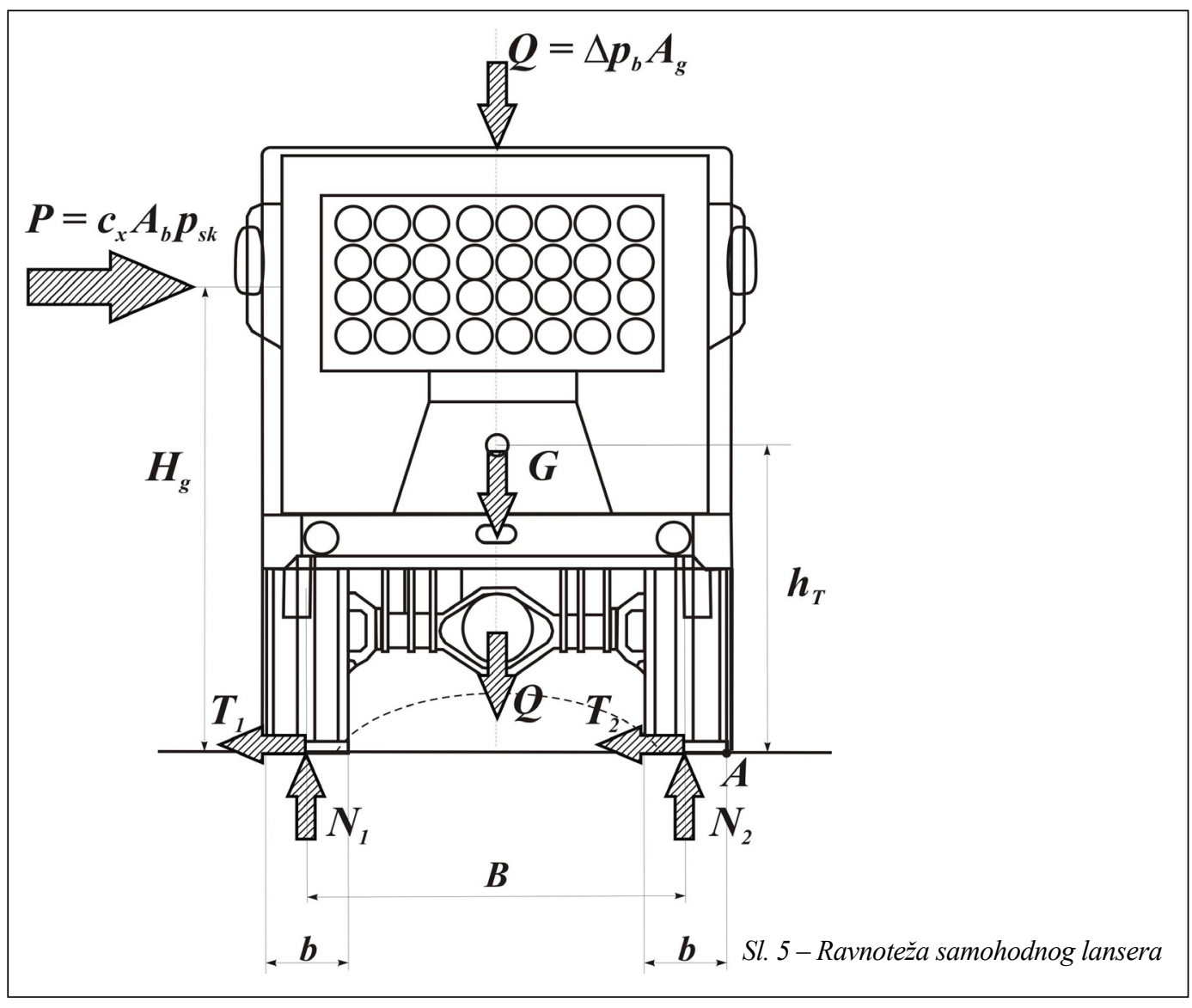

Pri tome se usvaja koeficijent otpora na dejstvo udarnog talasa $\mathrm{c}_{\mathrm{y}} \cong 1,2$ za profil prostornog paralelograma siluete samohodnog vozila [4], dok se kao površina $A_{b}$ usvaja bočna silueta lansera.

Navedena analiza odnosi se na uslove translatornog pomeranja pod dejstvom ravnomerno raspoređene sile natpritiska.

Poseban uslov stabilnosti u odnosu na prevrtanje, kao što je napomenuto, zahteva poznavanje centra dejstva natpritiska. Ukoliko je položaj visine rezultujućeg natpritiska približno poznat i iznosi $\mathrm{H}_{\mathrm{g}}$, uslov stabilnosti od prevrtanja može se napisati u obliku sume momenata oko jedne uzdužne linije oslanjanja lansera na tlu (tačka A - slika 5):

$$
\begin{aligned}
& c_{y} \cdot \frac{2,5 \Delta p_{b}^{2}}{\Delta p_{b}+709205} A_{b} \cdot H_{g}- \\
& -\left(\Delta p_{b} \cdot A_{g}+G\right) \frac{B+b}{2}=0
\end{aligned}
$$

\section{Zaključak}

Sprovedena analiza može se koristiti u preliminarnoj oceni stabilnosti samohodnog lansera, ali ne i za detaljniju studiju borbene žilavosti. Prevashodni cilj ovog rada jeste da utvrdi približan fizički karakter i oceni amplitudno-frekventni karakter borbenih pobuda kojima su izloženi sredstvo i municija, a za koje ne po- 
stoje adekvatne prototipske i konstruktorske simulacije. Cilj je, dakle, da se preduzmu projektno-istraživačke mere koje bi sprečile neželjene efekte borbenih dinamičkih opterećenja. Kao što je iz prethodnog modeliranja uočeno, suština dinamičkih opterećenja municije iz sastava reaktivne artiljerije najčešće je vezana za profile udarnih opterećenja udarnih talasa različitog porekla. Pokazuje se da prostiranje udarnog talasa i njegovo primarno dejstvo podležu sličnim eksponencijalnim funkcijama, kao i dejstvo udara gasova rakete ili trzaja pri aktivno-reaktivnom lansiranju. Dakle, postoji osnova za jedinstveni tretman problema, sa aspekta preliminarne simulacije, za jedinstveno rešenje prigušenja i apsorbovanja udara $i$ jedinstveni tretman opasnosti $\mathrm{u}$ vidu standardizacije bezbednosnih tehničko-tehnoloških rešenja.

Ponašanje vozila pri dejstvu spoljašnjih sila samo je deo tretmana navedenih problema. Uslovi dinamičkog opterećenja i stabilnost lansera pri opaljenju primarni su konstruktorski zadatak za projektovanje svakog artiljerijskog oruđa sa aspekta mehanike balističkih sistema. Uslov borbene žilavosti pri dejstvu kontrabatiranja je strog kriterijum za stabilnost samohodnog lansirnog oruđa sa aspekta intenziteta dinamičkih sila. U vojnim krugovima uobičajeno je mišlje- nje da se pogođena ili približno pogođena oruđa u borbi mogu otpisati, pa odatle sledi da tretman dinamičkih sila nastalih okolnom eksplozijom ne treba razmatrati u fazi projektovanja. Ipak, savremena konstrukcijska rešenja oruđa zbog povećane preciznosti i zahteva za smanjenjem mase sve manje svojom robustnošću rešavaju problem borbenih opterećenja. Dakle, nameće se zaključak da je lanser sa veoma skupom i preciznom municijom u uslovima dejstva na borbenom položaju osetljiviji, pa tretman ispitivanja municije na udarna opterećenja usled dejstva eksplozije dobija na značaju. Slično je i pitanje prenošenja detonacije u skladištima i pokretnim logističkim stanicama, gde se vrši stokiranje ili priprema municijskih pakovanja za upotrebu na vatrenom položaju.

Literatura:

[1] Kari, A., Milinović, M.: Modeliranje kriterijuma borbene žilavosti višecevnog lansera pod dejstvom impulsne pobude eksplozije, OTEH 2005, Beograd 2005.

[2] Orlenko, L. P.: Fizika vzriva, Fizmatlit, Moskva, 2002.

[3] Jeremić, R.: Eksplozivni procesi, GŠ VJ Uprava za ŠiO VA, Beograd 2002

[4] Milinović, M.: Osnovi projektovanja raketa i lansera, Poglavlja iz projektovanja lansera, Mašinski fakultet Beograd, 2002.

[5] Karaštin, V. M., Katkov A. G., Rodčenko, V. V.: Osnovi proektirovanija sistem nazemnogo obespečenija, MAI, Moskva, 1998.

[6] Malikov, V. G.: Komisarik, S. F., Korotkov, D. M.: Nazemnoe oborudovanie raket, Voennoe izdatelstvo ministerstve oboroni SSSR, Moskva, 1971. 


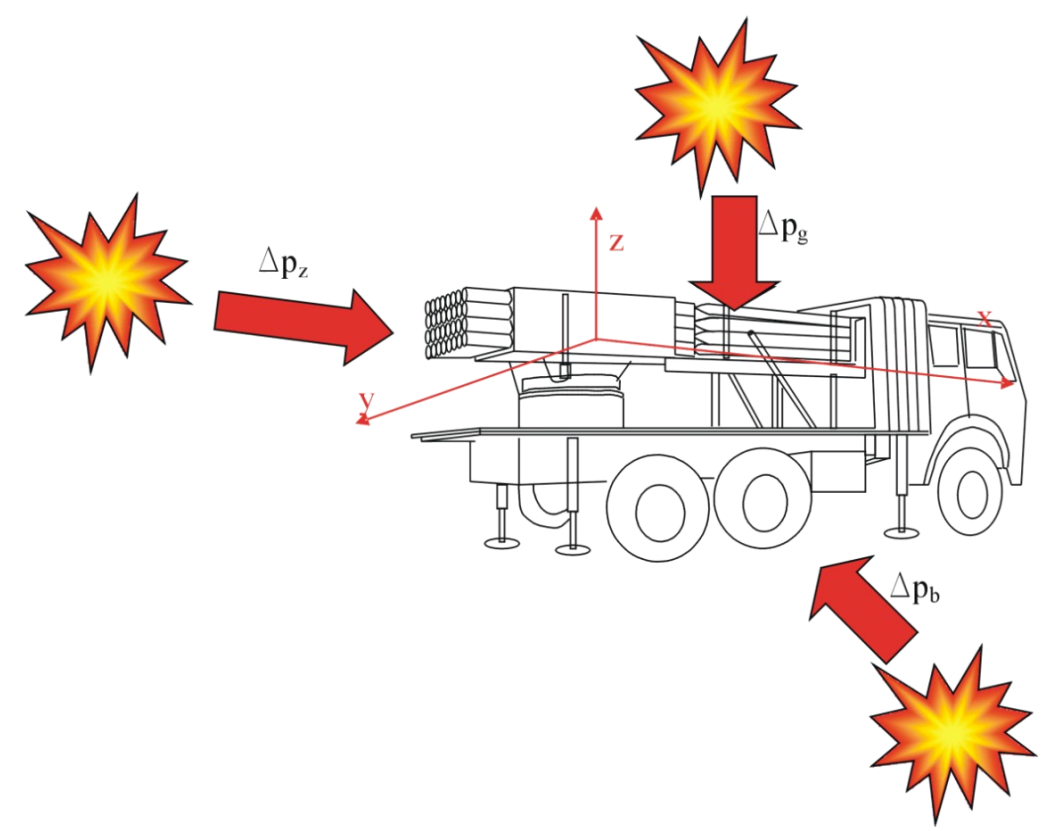

Sl. 1 - Fizički model pravca dejstva udarnog talasa na lanser

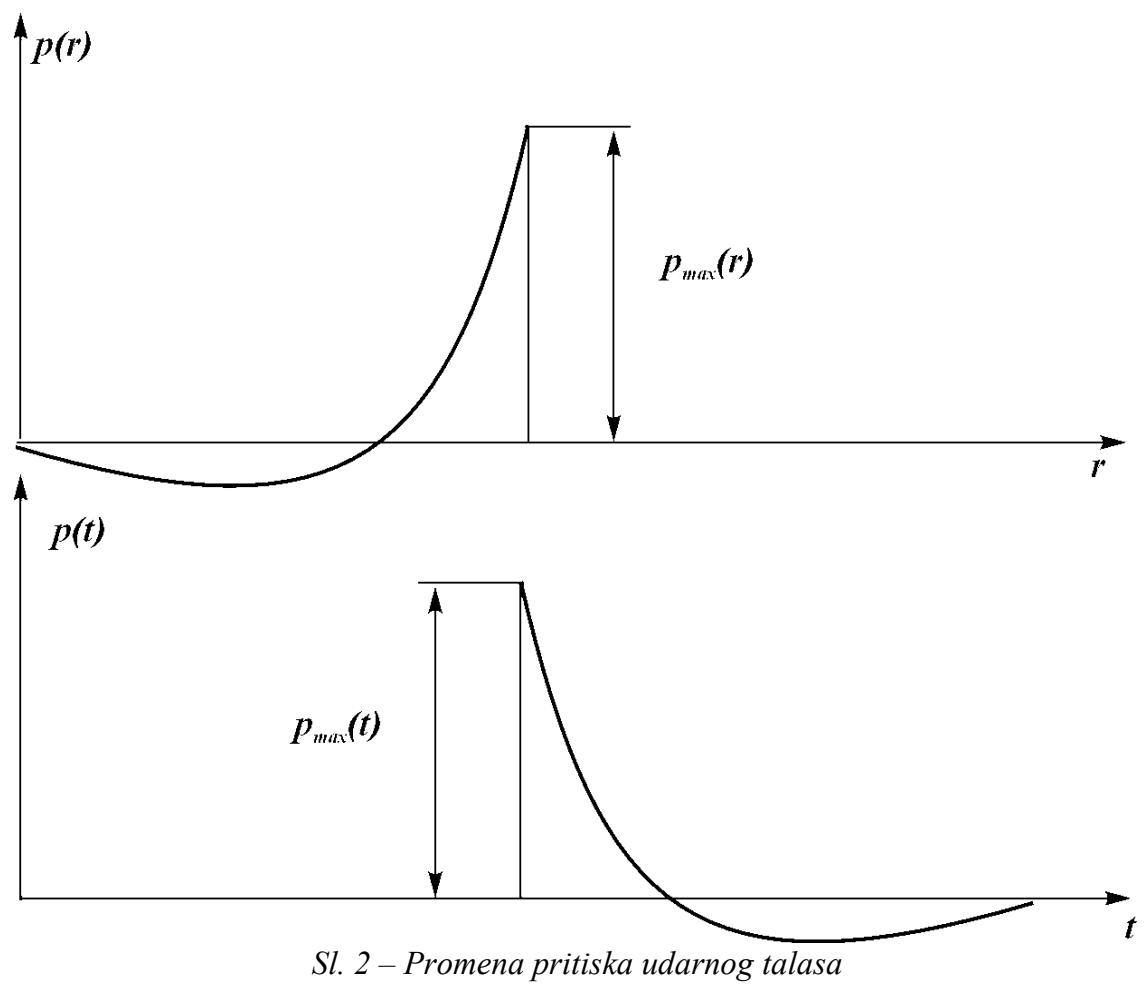




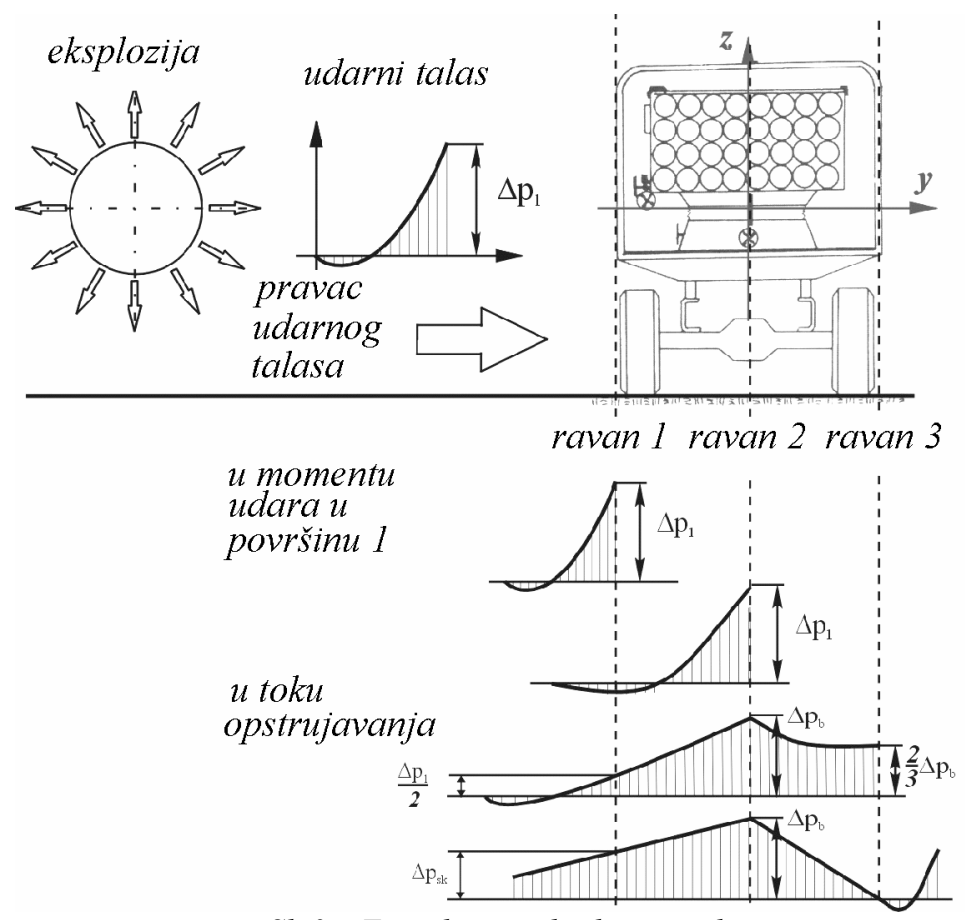

Sl. 3 - Faze dejstva eksplozije na lanser 

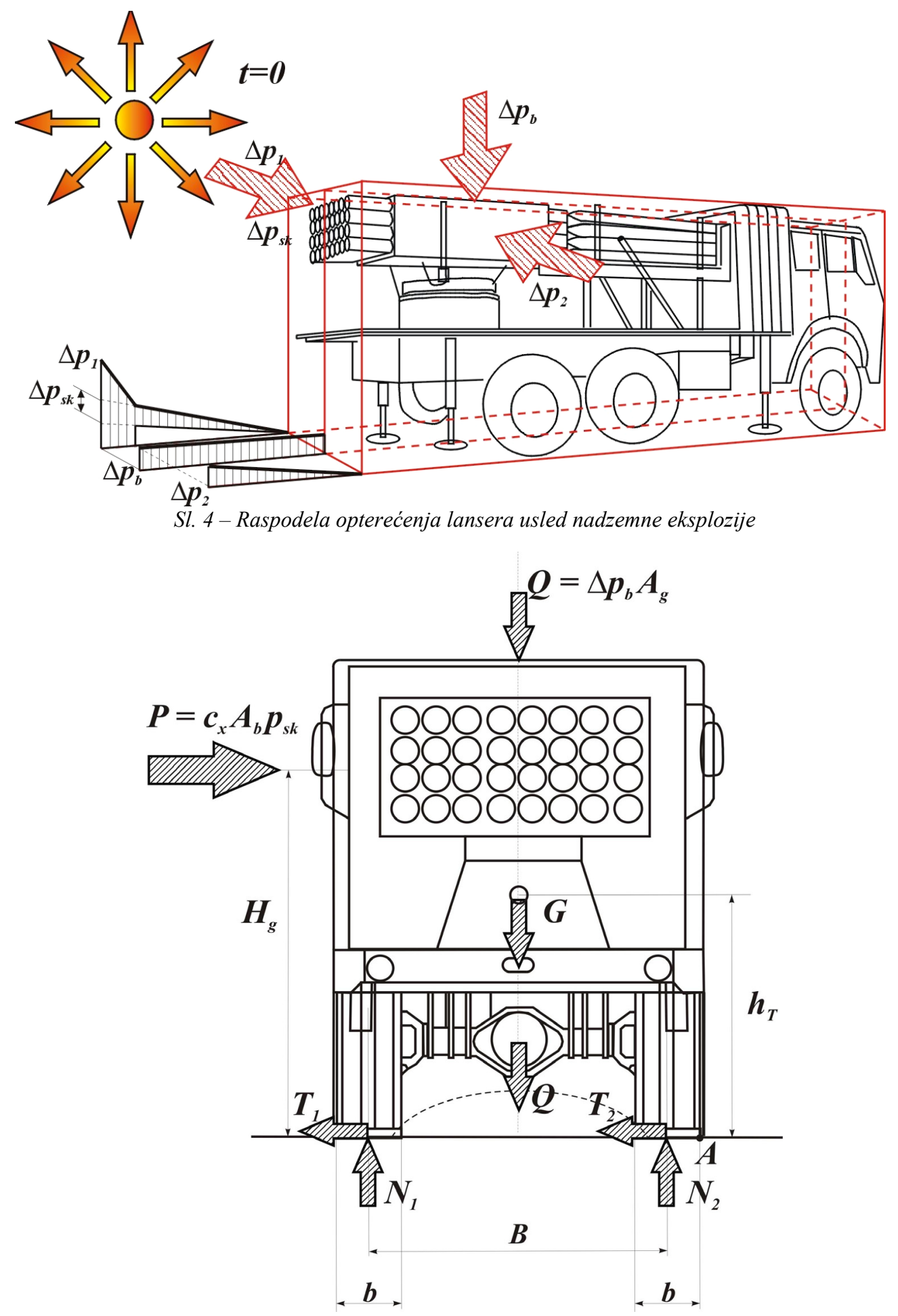

Sl. 5 - Ravnoteža samohodnog lansera 